\title{
APPLE SUPERFICIAL SCALD PREVENTION BY VAPOUR TREATMENTS
}

\author{
M. SIMČIČ, J. HRIBAR and R. VIDRIH \\ Biotechnical Faculty, Department of Food Science and Technology, University of Ljubljana, \\ 1000 Ljubljana, Jamnikarjeva 101. Slovenia
}

(Received: 13 September 1999; accepted: 19 December 1999)

\begin{abstract}
Superficial scald is a postharvest physiological disorder of apples characterized by browning of apple skin during prolonged storage. It has been hypothesized that conjugated triene hydroperoxides $(\mathrm{CTH})$ attack cell membranes causing membrane perturbation and the manifestation of the disorder. The purpose of this study was to compare the common synthetic antioxidant diphenylamine (DPA) treatment with postharvest vapour treatments for superficial scald prevention. Apples cv. 'Granny Smith' were treated with ethanol, methanol and »apple aroma vapours. The influence of these treatments on scald susceptibility and sensorial quality of apples was examined.

The ethanol treatments were effective in superficial scald prevention but they caused a high incidence of internal browning after two months of storage. The 10 day treatments at $20^{\circ} \mathrm{C}$ developed very pronounced internal browning after storage. The aroma treatment was the least effective in apple scald prevention but no internal disorders appeared after storage. Apples treated with methanol at $20^{\circ} \mathrm{C}$ retain a great deal of their initial green colour. Vapour treatments demonstrated to be potential methods for scald prevention. Additional research is needed to minimise the internal disorders of treated fruit.
\end{abstract}

Keywords: apples, superficial scald, post-harvest, ethanol, methanol, apple aroma, diphenylamine, colour

Superficial scald is a post-harvest physiological disorder that seriously limits the storage life of a number of apple and pear cultivars (INGLE \& D'SOUZA, 1989). It is characterized by the browning of apple skin and in extreme cases by the formation of hard black-brown patches which appear on the skin during or after prolonged cold storage. The biochemical basis of superficial scald was first suggested in the early seventies (ANET, 1969; HuElin \& COGGiOla, 1970a). It is well documented (ANET, 1969; GALLERANI et al., 1990) that development of scald is an oxidative process and strongly correlates with the increase in conjugated triene hydroperoxides (CTH). They are oxidative products of alpha-farnesene, a terpene produced in hypodermic cells of apples (HUELIN \& COGGIOLA, 1970b). It has been hypothesised that CTH attack cell 
membranes causing membrane perturbation (DU \& BRAMLAGE, 1995). Loss of cellular membrane integrity allows mixing of polyphenol oxidase with the phenolic substrates leading to browning (PIRETTI et al., 1994). The basic understanding of how scald develops is not yet well understood (DU \& BRAMLAGE, 1993; BRAMLAGE \& WEIS, 1997). Endogenous natural antioxidants present in apple skin are very important in superficial scald prevention (WANG et al., 1996). Phenolic components are the major group of plant antioxidants and they can also exhibit antimicrobial activity (ABRAM \& DONKO, 1999). This disorder can be effectively controlled by the synthetic antioxidants diphenylamine (DPA) and ethoxyquine (LURIE et al., 1989; BRAMLAGE et al., 1996). Because of the doubts about safety of these chemicals and increasing aversity towards chemically treated food, these postharvest treatments are no longer acceptable.

For these reasons there is an increased interest in alternative treatments that can prevent superficial scald disorder. New methods to prevent scald are ultra low oxygen storage treatments combined with ethyl alcohol (EtOH) vapours (SCOTT et al., 1995; GRAHAMANI \& SCOTT, 1998;) and prestorage heat treatment (LURIE \& KLEIN, 1990; LURIE et al., 1996).

Ethanol can retard ripening in some fruit such as tomatoes while it can stimulate ripening in blueberries, strawberries and kiwi fruit. Ethanol may initiate ripening of bananas or has no effect. It can slow down tomato fruit ripening by inhibiting ethylene action and synthesis, increasing $\mathrm{CO}_{2}$ production, decreasing chlorophyll loss and lycophene synthesis. Alcohol can also enhance the postharvest quality of tomatoes, blueberries and pears by increasing sugar content and flavour. It can reduce the incidence of chilling injury in cucumber cotyledons (YANURIATI et al., 1999).

The purpose of this study was to compare the common DPA treatment with postharvest vapour treatments. Apples cv. 'Granny Smith' were treated with ethanol, methanol and »apple aroma« vapours. The influence of these treatments on scald susceptibility and sensorial quality of apples was examined.

\section{Materials and methods}

\subsection{Materials}

Apples 'Granny Smith' cultivar were picked on 30.9.1997 (10 days before optimal harvest date) in the Krško region. Early picked apples are very susceptible to superficial scald. They were used in this experiment to ensure the appearance of the disorder after the storage. Samples were randomly taken and exposed to several treatments. 
Diphenylamine (DPA) was used in the form of commercial preparate $» \mathrm{NO}$ SCALD DPA 31 « (ELF Atochem Agri). Ethanol (98\%), methanol (99.8\%) and hexane (for spectrophotometry) were products of Merck (Germany). Natural apple aroma water solution was produced by ETOL-Celje (Slovenia).

\subsection{Vapour treatments}

In all vapour treatments 20 apples from the first picking date were treated in glass exiccator $(10 \mathrm{l})$ at $10{ }^{\circ} \mathrm{C}$ and $20^{\circ} \mathrm{C}$ for 10 days. The solvents $\left(100 \mathrm{~cm}^{3}\right.$ of $98 \%$ ethanol (ET); $100 \mathrm{~cm}^{3}$ of methanol (MT); $150 \mathrm{~cm}^{3}$ of apple aroma water solution (AR); $100 \mathrm{~cm}^{3}$ of distilled water as control (CO)) were added in an open petri plate at the bottom part of the exiccator which was later filled with 20 apples and closed tightly with the glass cover. After three days of treatment at $20{ }^{\circ} \mathrm{C}$ the concentration of $\mathrm{O}_{2}$ in exiccators was between $8.7 \%$ and $9.4 \%$. To minimise the effect of anoxic conditions the exiccators were purged with fresh air every three days, while this procedure was performed after five days for apples treated at $10^{\circ} \mathrm{C}$. All vapour treatments were performed in duplicates in the period between 27.10.-6.11.1997. For the DPA treatment apples were treated by immersion in water emulsion with $2000 \mathrm{ppm}$ diphenylamine (DPA). After all the treatments apples were stored under normal atmosphere conditions at $1{ }^{\circ} \mathrm{C}$ and $90 \% \mathrm{RH}$.

Methanol (toxic alcohol) was used in this experiment just for the comparison and to study the effects of simple alcohol on superficial scald. By the natural action of endogenous pectolytic enzymes, extremely small quantities of methanol are produced in apples during the decomposition of pectic polymers in the process of fruit maturation.

\subsection{Measurements}

1.3.1. Colour. Chromametric values $\left(\mathrm{L}^{*} \mathrm{a}^{*} \mathrm{~b}^{*}\right)$ of apple skin were measured during storage. The measurements were performed by MINOLTA chromometer CR$200 \mathrm{~b}$ (Japan).

All the measurements were done on each apple on the same signed points on the equatorial part of the fruit 5 times during the storage period.

1.3.2. Measurements of hydroperoxides. Levels of hydroperoxides (CTH) were measured by the following method. Six apples from each sample were peeled in the equatorial part. The cortex part of the peel was carefully removed by a sharp knife. On the opposite sides of the equatorial peel strip two circular segments $\left(2.5 \mathrm{~cm}^{2}\right)$ of the cuticle were cut with a cork borer (diameter $1.8 \mathrm{~cm}$ ). Twelve circular segments were put in $15 \mathrm{~cm}^{3}$ of hexane (Merck, for spectrophotometry) for $2 \mathrm{~min}$. 
Spectrophotometric measurements of clear hexane extract were performed between 200 and $300 \mathrm{~nm}$. The highest peak at $268 \mathrm{~nm}$ was used for the calculation of the $\mathrm{CTH}$ value in $\mathrm{A} \times 10^{4} \mathrm{~cm}^{-2}$.

After six moths of storage fruit samples were transferred to $20{ }^{\circ} \mathrm{C}$. One week later the incidence of superficial scald was recorded as a weighted Lurie index (L.I.) of scald intensity using the formula:

L.I. $=[(\%$ light scald $\times 1)+(\%$ medium scald $\times 2)+(\%$ severe scald $\times 4)] / 4$

light scald.................under $10 \%$ fruit skin surface affected

medium scald ...........11\%-40\% fruit skin surface affected

severe scald..............more than $40 \%$ fruit skin surface affected

The analyses were performed separately by 4 panellists.

1.3.3. Sensory analyses. After six months of storage the sensory evaluation was performed by 7 panellists ( 3 females, 4 males). The fruits were evaluated for juiciness, sourness and overall taste perception, ranged on a scale from 1 to 5 points ( 1 poor, 5 very good).

\section{Results and discussion}

During the first 4 months of storage the $\mathrm{CTH}$ value increased in all treatments (Fig. 1). In the period of maximal hydroperoxide values (approximately 140 days after harvest), the first appearance of superficial scald was observed. After that period the $\mathrm{CTH}$ value declined rapidly in all treatments. Apples treated at $20^{\circ} \mathrm{C}$ had accumulated less hydroperoxides in their skin during the storage.

The CTH value of vapour treated apples were lower than the control. Ethanol and methanol treatments at $20^{\circ} \mathrm{C}$ were the most effective ways to lower the $\mathrm{CTH}$.

After 6 months of storage apples were scored for scald as described in Materials and methods. In the storage period 1997/98 apples were extremely susceptible for superficial scald. More than $90 \%$ of non treated 'Granny Smith' apples, stored at $1{ }^{\circ} \mathrm{C}$ in normal atmosphere were affected by the disorder. Also in apples treated with DPA, 23\% of the fruits were affected by superficial scald (Fig. 2).

Ethanol treatment for 10 days at $10{ }^{\circ} \mathrm{C}$ was the most effective for the prevention of superficial scald. Under the conditions of our experiment this treatment was even more effective than DPA. The apples treated at $20^{\circ} \mathrm{C}$ exhibited ethanol injuries on the skin. Methanol treatment at $10^{\circ} \mathrm{C}$ was less effective than ethanol. The aroma treatment reduced the scald intensity but the effect was not pronounced $(52 \%$ of apples was affected by superficial scald). The non treated apples had very severe scald at both temperatures (Fig. 2). The apples treated with ethanol and methanol had high incidence of internal browning. This disorder was very pronounced in apples treated for 10 days at $20{ }^{\circ} \mathrm{C}$. 


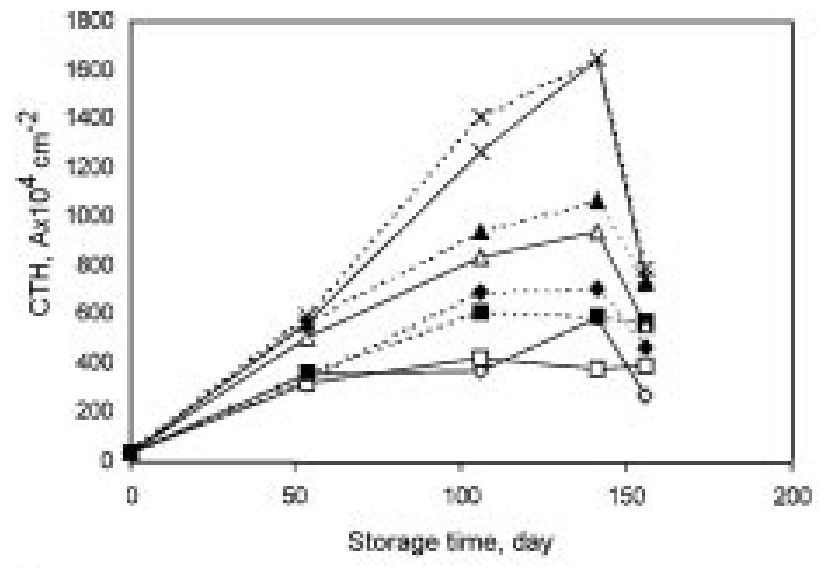

Fig. 1. Changes in hydroperoxide values in apples 'Granny Smith' after different vapour treatments at $10{ }^{\circ} \mathrm{C}$ and $20^{\circ} \mathrm{C}$ for 10 days (ET-ethanol, MT-methanol, AR-aroma, CO-control). $-\nabla-\mathrm{ET}-20^{\circ} \mathrm{C}$; --- $---\mathrm{ET}-$ $10^{\circ} \mathrm{C} ;-\square-\mathrm{MT}-20^{\circ} \mathrm{C}$; ---口-- $\mathrm{MT}-10^{\circ} \mathrm{C} ;-\Delta-\mathrm{AR}-20^{\circ} \mathrm{C} ;---\mathbf{A}---\mathrm{AR}-10^{\circ} \mathrm{C} ;-\mathrm{X}-\mathrm{CO}-20^{\circ} \mathrm{C}$; ---X--- $\mathrm{CO}-10^{\circ} \mathrm{C}$

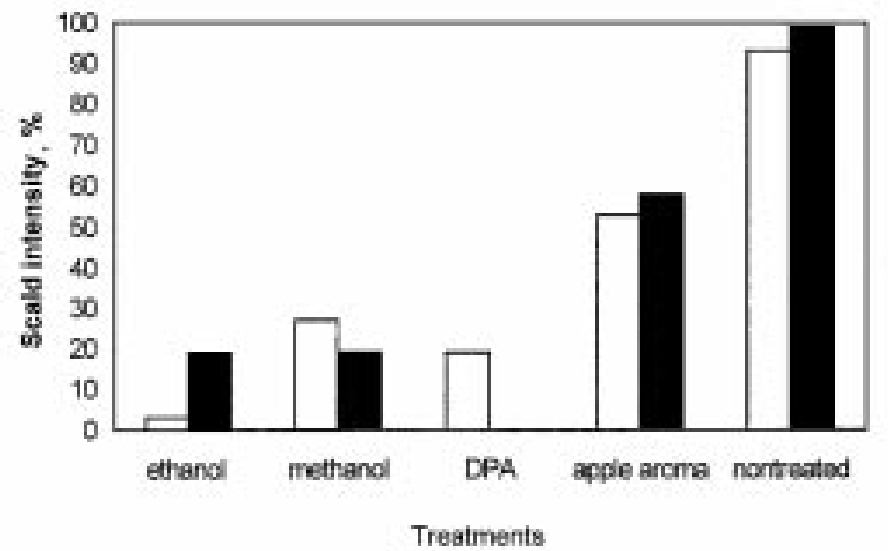

Fig. 2. Scald intensity in vapour treated apples 'Granny Smith' at $10^{\circ} \mathrm{C}$ and $20^{\circ} \mathrm{C}$ for 10 days after 6 months of storage compared with DPA treatment. $\square: 10^{\circ} \mathrm{C} ; \mathbf{\square}: 20^{\circ} \mathrm{C}$ 
In the case of methanol treatment severe internal breakdown disorder was detected. In the experiments where ethanol was used to prevent superficial scald on apples stored in plastic bags no internal damages of fruit was observed (SCOTT et al., 1995; GHAHRAMANI \& SCOTT, 1998). The change of the chromametric a* value demonstrated the effect of vapour treatments on the intensity of the green colour of the apple skin (Fig. 3). The intensity of deep green colour is one of the most important quality parameters for 'Granny Smith' apples. For good consumer acceptance the preservation of green colour during storage is important. Apples treated with methanol at $20{ }^{\circ} \mathrm{C}$ preserved a great deal of the initial green colour. As the skin turns darker, it can be speculated that methanol vapour had a slightly phytotoxic effect which is manifested as a darker green colour of the fruits. Ethanol treatment at $20^{\circ} \mathrm{C}$ has the highest degreening effect. The colour difference of 1 , measured as a* value in the range that was performed in our experiment, can be detected by the consumer. The measurements demonstrate that there was a pronounced visual difference between treatments performed at $20^{\circ} \mathrm{C}$.

Methanol treatment had a negative influence on the sensory analyses after storage. Apples treated with DPA had the best results in all measured sensority attributes. Good sensory quality was inversely correlated with the increasing incidence of internal disorders in fruits.

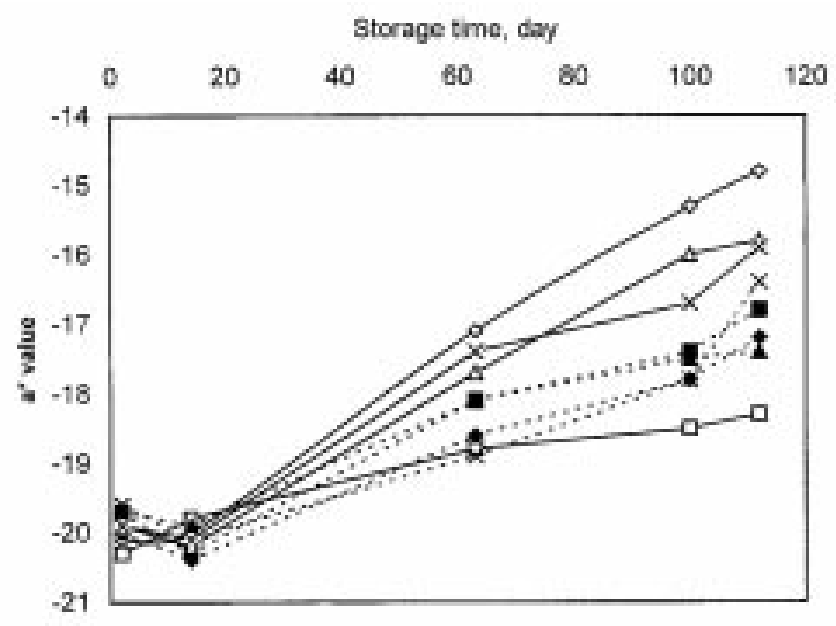

Fig. 3. Chromametric a* value of apples 'Granny Smith' after different vapour treatments at $10{ }^{\circ} \mathrm{C}$ and $20{ }^{\circ} \mathrm{C}$ for 10 days ( ET-ethanol, MT-methanol, AR-aroma, CO-control). $-\diamond-\mathrm{ET}-20^{\circ} \mathrm{C} ;---\downarrow--\mathrm{ET}-10^{\circ} \mathrm{C} ;-\square-$ $\mathrm{MT}-20^{\circ} \mathrm{C}$; --- --- $\mathrm{MT}-10^{\circ} \mathrm{C} ;-\Delta-\mathrm{AR}-20^{\circ} \mathrm{C} ;--\mathbf{\Delta}--\mathrm{AR}-10^{\circ} \mathrm{C} ; \quad-\mathrm{X}-\mathrm{CO}-20^{\circ} \mathrm{C}$;

$$
\text { ---X-- } \mathrm{CO}-10^{\circ} \mathrm{C}
$$




\section{Conclusions}

The ethanol treatments were effective in superficial scald prevention. The results were better than with the DPA treatment. The main disadvantage of alcohol treatments in these conditions is the high incidence of internal browning after two months of storage. The 10 day treatments at $20^{\circ} \mathrm{C}$ developed a very pronounced internal browning after storage. In case of methanol treatment severe internal breakdown was detected. The aroma treatment was the least effective in apple scald prevention but no internal disorders appeared after storage.

It was demonstrated that exogenous ethanol vapour gave effective control of superficial scald (GHAHRAMANI \& SCOTT, 1998). Similar results were achieved with endogenous production of ethanol caused by low $\mathrm{O}_{2}$ stress (LURIE \& PESIS, 1992). The prevention of superficial scald by low $\mathrm{O}_{2}$ may be partially affected due to ethanol production caused by these treatments. In our research, there is an evidence that ethanol, methanol and apple aroma compounds have similar effects on superficial scald prevention. Apples treated with methanol at $20{ }^{\circ} \mathrm{C}$ retain a great deal of their initial green colour. Further research is required to determine the mode of action of volatile compounds (KNEE \& HATFIELD, 1981; YANURIATI et al., 1999) and to minimise the internal disorders caused by vapour treatments.

The authors would like to express their gratitude to Mr. Gregor JEJČIČ for his assitance and technical support.

\section{References}

ABRAM, V. \& DONKO, M. (1999): Tentative identification of polyphenols in Sempervivum tectorum and assesment of antimicrobial activity of Sempervivum L. J. agric. Fd Chem., 47, 485-489.

ANET, E. F. L. J. (1969): Autooxidation of alpha farnesene. Aust. J. Chem., 22, 240-241.

ANET, E. F. L. J. \& COGGIOLA, I. M. (1974): Superficial scald, a functional disorder of stored apples. Control of alpha farnesene autoxidation. J. Sci. Fd Agr., 25, 293-298.

BRAMlarGE, W. J., POTTER, T. L. \& JU, Z. (1996): Detection of diphenylamine on surface of nontreated apples. J. agric. Fd Chem., 44, 1348-1351.

BRAMLARGE, W. J. \& WEIS, S. A. (1997): Effects of temperature, and rainfall on superficial scald in apples. Hort. Sci., 32, 808-811.

DU, Z. \& BRAMLAGE, W. J. (1993): A modified hypothesis of role of conjugated triens in superficial scald development in stored apples. J. Amer.-Soc. Hort. Sci., 118, 807-813.

DU, Z. \& BRAMLAGE, W. J. (1995): Peroxidative activity of apple peel in relation to development of poststorage disorders. Hortscience, 30, 205-209. 
Gallerani, G., Pratella, G. C. \& BuDiNI, R. A. (1990): The distribution and role of natural antioxidant substances in apple fruit affected by superficial scald. Adv. Hortic. Sci., 3, 144-146.

GHAHRAMANI, F. \& SCOTT, K. J. (1998): The action of ethanol in controlling superficial scald of apples. Aust. J. agric. Res., 2, 199-205.

Huelin, F. E. \& COGgiolA, I. M. (1970a): Superficial scald, a functional disorder of stored apples. Evaporation of alpha farnesene from the fruit. J. Sci. Fd Agric., 21, 82-86.

Huelin, F. E. \& COGGiolA, I. M. (1970b): Superficial scald, a functional disorder of stored apples. 5. Oxidation of alpha farnesene and its inhibition by diphenylamine. J. Sci. Fd Agr., 21, 44-48.

INGLE, M. \& D'SOUZA, M. C. (1989): Physiology and control of superficial scald of apples. Hortscience, 24, 28-31.

KNEE, M. \& HATField, S. G. S. (1981): The metabolism of alcohols by apple fruit tissue, J. Sci. Fd Agric., $32,593-600$.

LURIE, S. \& KLEIN, J. D. (1990): Heat treatment of ripening, apples: differential effects on physiology and biochemistry. Physiol. Plant., 78, 181-186.

LURIE, S. \& PESIS, E. (1992): Effect of acetaldehyde and anaerobiosis as postharvest treatments on the quality of peaches and nectarines. Postharvest Biol. Technol., 1, 317-326.

LURIE, S., KLEIN, J. \& BEN-AIRE, R. (1989): Physiological changes in diphenylamine treated Granny Smith apples. Isr. J. Bot., 38, 199-207.

LURIE, S., FALLIK, E. \& KLEIN, J. D. (1996): The effect of heat treatment on apple epicuticular wax and calcium uptake. Postharvest Biol. Technol., 8, 271-277.

Piretti, M. V., Gallerani, G. \& Pratella, G. C. (1994): Polyphenol fate and superficial scald in apple. Postharvest Biol. Technol., 4, 213-224.

SCOTT, K. J., YuEN, C. M. C. \& GHAHRAMANI, F. (1995): Ethanol vapour - a new antiscald treatment of apples. Posharvest Biol. Technol., 6, 201-208.

WANG, H., CAO, G. \& PRIOR, R. L. (1996): Total antioxidant capacity of fruits. J. agric. Fd Chem., 44, 701-705.

YANURIATI, A., SAVAGE, G. P. \& ROWE, R. N. (1999): The effects of ethanol treatment on the metabolism, shelf life and quality of stored tomatoes at different maturities and temperatures. J. Sci. Fd Agric., 59, 995-1002. 